\title{
Adaptability and stability of peach yield of cultivar BRS Libra grafted on different rootstocks in the subtropics
}

Crop Breeding and Applied Biotechnology 20(2): e314620218, 2020 Brazilian Society of Plant Breeding. Printed in Brazil http://dx.doi.org/10.1590/198470332020v20n2a34

\section{Alice S. Santana ${ }^{1 *}$, Alison Uberti ${ }^{1}$, Maike Lovatto ${ }^{2}$, Jean do Prado $^{3}$, Mateus Velho dos Santos ${ }^{3}$, João R. A. S. C. Rocha ${ }^{1}$, Newton Alex Mayer ${ }^{4}$ and Clevison Luiz Giacobbo ${ }^{3}$}

\begin{abstract}
The objective was to evaluate the adaptability and yield stability of different peach rootstock genotypes in subtropical climate in an experiment in Chapecó, Santa Catarina, Brazil. Twenty-one rootstocks under the scion cultivar 'BRS Libra' and one genotype from self-rooted nursery trees were evaluated. The 22 genotypes were evaluated as fruit set and fruit yield in the growing seasons 2014/15, 2015/16, 2016/17 and 2017/18. Adaptability and stability were measured by the GGE biplot method. In the four years of evaluation, plants from self-rooted nursery trees had higher fruit set, yield as well as greater stability. On the other hand, the instability of plants grown on rootstocks from species other than the scion cultivar was greater. It can be concluded that under the tested conditions, the self-rooted genotype of 'BRS Libra' is a potential alternative for peach growers.
\end{abstract}

Keywords: Mixed models, peach, performance consistency, Prunus.

\section{INTRODUCTION}

Economically, peach (Prunus persica (L.) Batsch) is the third most important fruit species in temperate zones and one of the main species of the Rosaceae family (Forcada et al. 2014). Breeding programs have developed peach cultivars with low chilling requirement, to allow cultivation in places with low incidence of cold. These cultivars are responsible for the expansion of commercial peach cultivation, particularly in Brazil, where climatic conditions are highly variable (Scariotto et al. 2013).

In the humid subtropical regions of southern Brazil, conflicting tropical and polar air masses result in insufficient cold accumulation in some years but also in a risk of late frost during the flowering stage. In addition, temperatures above $20^{\circ} \mathrm{C}$ during the endodormancy period, considered undesirable, are also frequent in these regions (Pio et al. 2019).

Cultivars with a low chilling requirement for endodormancy release can make peach production in subtropical regions possible and successful. Cultivar BRS Libra, commonly grown in southern Brazil, meets this demand, with a chilling requirement of less than 200 hours (Raseira et al. 2014, Pio et al. 2019, Fadón et al. 2020). The fruit quality of this early-ripening cultivar is excellent, both for fresh consumption and industry. Thus, it is believed that cultivar BRS Libra may be interesting, mainly for small farmers who sell fresh fruit (Raseira et al. 2010)
*Corresponding author: E-mail: alice.santana4@ufv.br (D) ORCID: 0000-0003-3798-8748

Received: 07 February 2020 Accepted: 27 May 2020 Published: 26 June 2020

${ }^{1}$ Universidade Federal de Viçosa, Avenida Peter Henry Rolfs, Campus Universitário, 36.570-900, Viçosa, MG, Brazil

2 Universidade Estadual de Maringá, Avenida Colombo 5790, Jardim Universitário, 87.020900, Maringá, PR, Brazil

${ }^{3}$ Universidade Federal da Fronteira Sul, Rodovia SC 484, Fronteira Sul, 89.815-899, Chapecó, SC, Brazil ${ }^{4}$ Embrapa Clima Temperado, Rodovia 392 BR, 96.010-971, Pelotas, RS, Brazil 
Fruit yield, however, is a quantitative, low heritability trait, controlled by several small effect genes and highly influenced by the environment and genotype $\times$ environment (GE) interaction (Dogra and Kumar 2018). The GE interaction is an important information for breeders because it reflects the yield variation not explained by the individual effects of genotype and environment (Vaezi et al. 2018). As is the case with many other fruit tree crops, commercially producing peach trees consist of a combination of two plants, i.e., the rootstock and the scion cultivars, which may belong to the same or to different species.

To reduce the negative effects of GE interaction, it is important to identify genotypes with adaptability and stability across multiple environments (Couto et al. 2015). In this context, stability and adaptability express the genotype reaction to environmental variation. Adaptability is a natural reaction of a genotype to survive and reproduce. Stability is defined as the ability to respond with a minimum of interaction with environmental variation (Eberhart and Russell 1996).

Some recent methodologies adequately explain the main effects (genotypes and environments), among which the GGE (genotype and genotype $\times$ environment interaction) biplot methodology stands out. This technique integrates analysis of variance with principal component analysis and is more efficient at explaining a high proportion of the sum of squares for the interaction than the combined analysis of variance (Abreu et al. 2019).

In annual species, genotype behavior prediction in growing environments is commonly estimated for different cultures using different methodologies (Luz et al., 2018). However, the assessment of perennial or semiperennial plants, including peach, is more difficult. As is well-known, fruit yield and quality depend on the scion/rootstock combination but may also be influenced by the rootstock (Forcada et al. 2019). Rootstocks are an essential component of modern fruit production because of their capability of mediating the adaptability of scion cultivars to diverse environmental conditions and cultural practices (Mestre et al. 2017).

However, very few studies have evaluated the interaction between scion cultivars and different rootstocks (released or not yet released), cultivars (of consumer preference) and growing seasons (different cultivation conditions), due to the high time and cost requirements. (Orazem et al. 2011, Mestre et al. 2017, Jimenes et al. 2018, Gonçalves et al. 2019). The cited studies tested other scion cultivars than BRS Libra. In this context, the objective was to evaluate the potential effect of rootstocks on the adaptability and stability of fruit yield and fruit set of "BRS Libra" peach trees in the subtropics, by the GGE biplot methodology.

\section{MATERIAL AND METHODS}

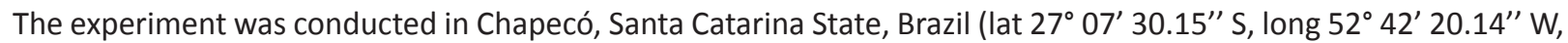
alt $605 \mathrm{~m}$ asl). According to Köppen, the local climate is classified as subtropical humid (Cfa). The climate data of the study period are presented in Figure 1. The local soil is clayey and classified as Latossolo Vermelho Distroférrico (Oxisol), with a basic $\mathrm{pH}$, i.e., requiring no liming.

Evaluations were carried out in the growing seasons 2014/15, 2015/16, 2016/17 and 2017/18. At the beginning of the evaluations, the trees were three years old. A total of 21 clonal rootstocks grafted under scion 'BRS Libra' were studied (Table 1). 'BRS Libra' is a cultivar with low chilling requirement (less than 200 hours), high yield (mean of $20 \mathrm{t}$ $\mathrm{ha}^{-1}$ ) and excellent fruit quality for both fresh consumption and industrial use. It is adapted to the south and southeast of Brazil and is currently being investigated in Huelva (Southern Spain) (Raseira et al. 2010).

As control plants, self-rooted nursery trees (without rootstock) of cultivar BRS Libra were used, i.e., a total of 22 different genotype combinations. The self-rooted cultivar BRS Libra was chosen as control to determine the rootstock effect on peach yield.



Figure 1. Climate data from May to December of 2015 to 2018 in Chapecó, Santa Catarina, Brazil. Source: Estação Climatológica de Chapecó, EPAGRI-CIRAM. 
Therefore, any change in the agronomic performance of the grafted in comparison with self-rooted trees can only be ascribed to the rootstock effect, since all trees were exposed to the same agronomic management and climatic conditions. Furthermore, the use of self-rooted plants of the scion cultivar is an interesting possibility that is being exploited for numerous plant species, including peach (Yammoto et al. 2013, Mayer et al. 2018, Fumuro 2019, Patil et al. 2019). The use of self-rooted plants shortens the production time in tree nurseries, exempts the use of rootstocks and excludes the risks of graft incompatibility (Jimenes et al. 2018).

All rootstocks were cloned by cutting. Plants were grafted by chip-budding on BRS Libra buds. The experiment was arranged in randomized blocks with four replications. The experimental plots consisted of one plant, planted in $5 \times 2 \mathrm{~m}$ row spacing, arranged in $\mathrm{Y}$ shape, as proposed by Grossman and Dejong (1998).

The management of diseases, insects and weeds, pruning and fertilization were carried out according to recommendations for peach (Raseira et al. 2014). No irrigation system and dormancy- breaking chemicals were adopted. As described by Raseira et al. (2014), thinning was performed by removing fruits with a longitudinal diameter range beyond $15-20 \mathrm{~mm}$ : on medium-sized shoots, four to five fruits spaced $8-10 \mathrm{~cm}$ apart were spared; and on thinner shoots, one to two fruits spaced $12-15 \mathrm{~cm}$ apart. No fruits were left on mixed branches (carrying fruit and branch buds) without leaves.

To evaluate fruit set percentage, two mixed branches at mid plant height were selected, one on each main branch. On each secondary branch, the number of flowers and afterwards fruit set (before thinning) were counted to compute the flower to fruit set ratio. The result was expressed in percentage (\%).

Fruits were harvested every 3 to 4 days by hand, selecting the fruits for picking on the basis of the change of the main color from green to yellow and the size. To evaluate fruit yield, the total number of fruits was multiplied by the mean fruit weight of each genotype and the results were expressed in $\mathrm{kg} \mathrm{tree}^{-1}$. Total number of fruits was calculated by counting all fruits picked per harvest. Thereafter, the fruits were taken to the laboratory, where they were counted and weighed on a semi-analytical scale (model UX-4200H, Shimadzu (C)), to two decimal places, to determine the mean fruit weight.

Data normality and homogeneity were checked by Shapiro-Wilk and Bartlett tests, respectively. Then, variance analysis (ANOVA) was performed, grouping the genotypes by the Scott-Knott test $(p<0.05)$.

To analyze adaptability and stability of fruit set percentage and yield per plant, the GGE (genotype main effect plus genotype - environment interaction effect) biplot methodology was used, as explained by Yan and Kang (2003)?, based on the following model:

$$
Y_{i j}-\bar{Y}_{j}=\lambda_{1} \xi_{i 1} \eta_{i 1}+\lambda_{2} \xi_{i 2} \eta_{i 2}+\xi_{i j}
$$

where $Y_{i j}$ represents the mean of genotype $\mathrm{i}$ in year $\mathrm{j}$; $\mathrm{j}$ the mean of all genotypes in year $\mathrm{j} ; \mathrm{j} ; \lambda_{1} \xi_{\mathrm{i} 1} \eta_{\mathrm{i} 1}$ the first major component (PC1); $\lambda_{2} \xi_{i 2} \eta_{i 2}$ the second major component (PC2); $\lambda_{1}$ and $\lambda_{2}$ are the eigenvalues associated with PC1 and $P C 2$, respectively, for genotype $i \eta_{j 1}$ and $\eta_{j 2}$ the eigenvalues associated with PC1 and PC2, respectively, for year $j$; and $\xi_{i j}$ is the model error (Yan and Kang 2003). 
The alternate bearing index (I), which expresses how much the fruit yield oscillates between so-called 'on' years with high and 'off' years with low yields, was calculated as proposed by Hoblyn et al. (1936):

$$
I=\frac{\sum_{\mathrm{t}=2}^{\mathrm{n}}\left(\left|y_{t}-y_{\mathrm{t}-1}\right|\right) /\left(\left|y_{t}+y_{\mathrm{t}-1}\right|\right)}{n-1}
$$

where $I$ is the sum of the absolute yield difference between two successive years $t$ and $t-1$, ranked by the sum of yields over these two years; and then standardized for the total number of years in the time series $n$, minus one. I varies between 0 and 1 , where $I=0$ represents no alternate bearing and $I=1$ strict alternate bearing behavior. This index can be used to confirm the effect of a high genotypic stability. Finally, Pearson's (phenotypic) correlation was applied to the evaluated years. Softwares R (R Core Team 2016) and GENES (Cruz 2006) were used for statistical data rating.

\section{RESULTS AND DISCUSSION}

Genotypes, growing seasons and GE interaction were significant for fruit set and yield (Table 2). During the four growing seasons, the results for fruit set and yield per plant differed between genotype combinations (Figure 2). As observed by Iglesias et al. (2019), the rootstock and year $x$ rootstock interaction were the main sources of variability for both traits, respectively.

Table 2. Source of variation, degree of freedom (df), and mean squares for fruit set and yield for 22 peach genotypes in four growing seasons, from 2015 to 2018

\begin{tabular}{lccc}
\hline Sources of variation & df & \multicolumn{2}{c}{ Mean square } \\
\cline { 3 - 4 } & & Fruit set & Yield \\
\hline Genotype (G) & 21 & $453^{* * *}$ & $188^{* * *}$ \\
Years & 3 & $17.48^{* * *}$ & $5.29 * * *$ \\
Genotype $\times$ Year & 63 & $168^{* * *}$ & $52^{* * *}$ \\
Error & 252 & 13 & 4 \\
\hline Mean & & 19.04 & 9.76 \\
CV (\%) & & 13.63 & 11.96 \\
\hline
\end{tabular}

*** Statistically significant differences at $\mathrm{p}<0.01$.
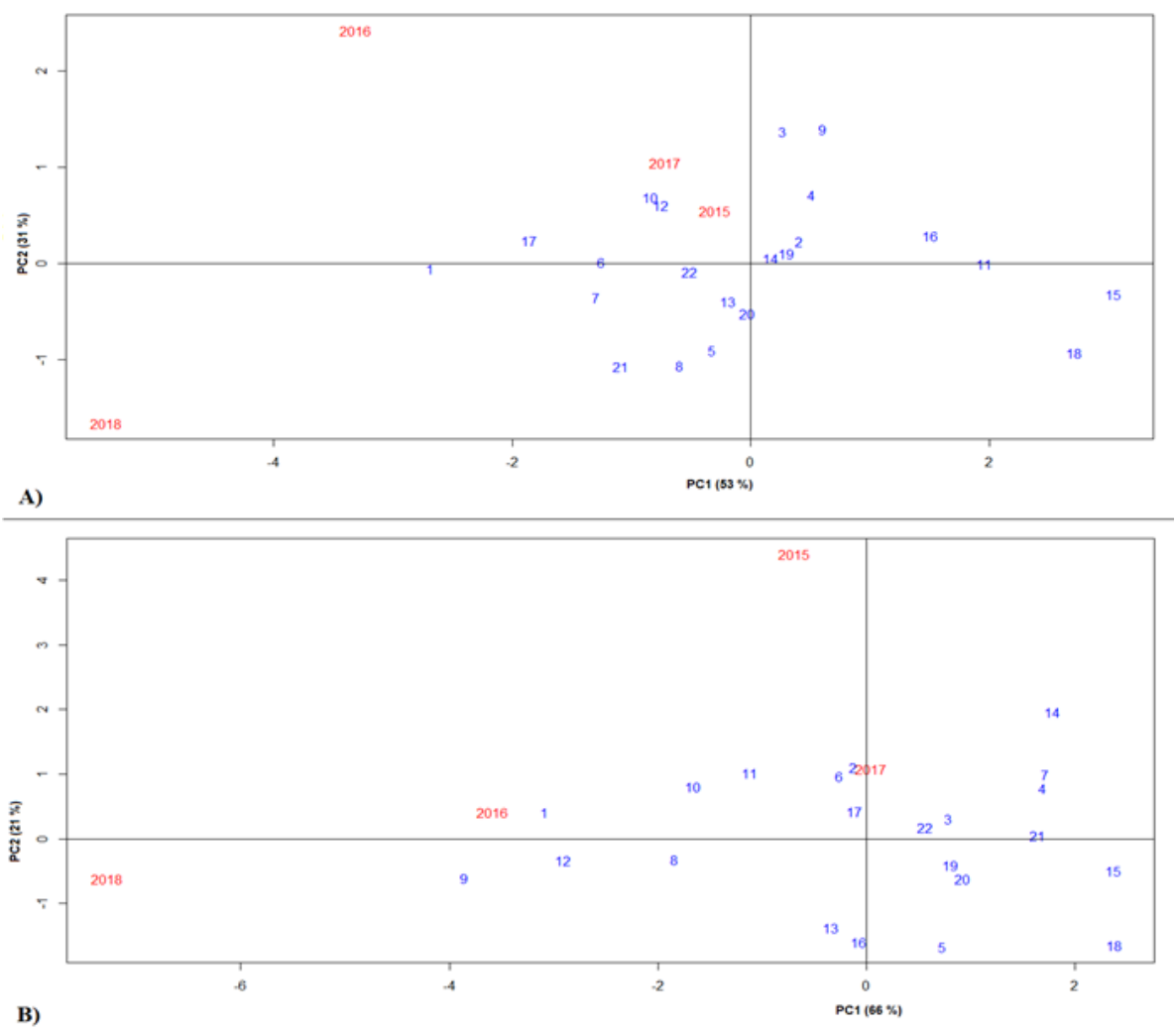

Figure 2. GGE (genotype and genotype-environment interaction) biplot of 22 peach genotypes evaluated over four growing seasons (2015 to 2018) for peach yield (Kg per trees) (A) and fruit set (\%) (B) in Chapecó, state of Santa Catarina, Brazil. Self-rooted (1), Barrier (2), Cadaman (3), Capdeboscq (4), Clone 15 (5), De Guia (6), Flordaguard (7), G × N9 (8), GF 677 (9), I-67-52-4 (10), Ishtara (11), México Fila 1 (12), Nemared (13), Okinawa (14), Prunus mandshurica (15), Rigitano (16), Rosaflor (17), Santa Rosa (18), Late 01 (19), Tsukuba-1 (20), Tsukuba-2 (21) and Tsukuba-3 (22). 
The principal component analyses in this study showed that $87 \%$ (Figure $2 \mathrm{~B}$ ) and $85 \%$ (Figure $2 \mathrm{~A}$ ) of the total variability observed for fruit set and plant yield can be explained by the first two principal components (PC1 and PC2). Thus, PC1 and PC2 are informative and can explain the interactions between genotypes and GE. In the GGE biplot model, the effects of genotype and GE interaction are multiplicative (Hadasch et al. 2017). A multiplicative model can be generated by dropping the main effect of genotypes, of environment or both main effects. The residuals from this array then constitute the array of interactions and the multiplicative interaction terms are estimated from the singular value decomposition (SVD) of this array (Dias et al. 2003).

By the GGE biplot method, only the effects of the genotype and GE interaction are considered relevant, and both should be considered simultaneously in scion and rootstock cultivar evaluations. The two main axes represent most of the data variation, considering the environmental effect as fixed, i.e., the variation in fruit set percentage or yield per plant would be the result of only the genotype and GE interaction (Yan and Kang 2003).

A PC1 value close to the origin indicates a genotype mean close to the overall mean (represented by the origin of the lines). The farther the value shifts away towards the right of the origin, the higher is the value of the variable and the more adapted is the genotype (in this case, for fruit set or yield). A PC2 value close to zero indicates more stable genotypes. The biplot chart can also identify the ideal environment (growing season), indicated by its high value for PC1 and a value close to zero for PC2 (Yan and Kang 2003).

The growing season 2017 brought severe frosts. For example, in July 2017, the lowest temperature observed in the last 30 years $\left(-3^{\circ} \mathrm{C}\right)$ was recorded (Figure 1). The incidence of frost in July coincided with the period of full flowering of the crop. Consequently, flowers exposed to the intense cold were frozen and subsequently aborted by the plant, due to cellular damage of the tissue. For this reason, fruit set was lowest in 2017 (Table 3).

Table 3. Mean grouping test for fruit set for 22 peach genotypes in four growing seasons, from 2015 to 2018

\begin{tabular}{|c|c|c|c|c|}
\hline \multirow[t]{2}{*}{ Genotypes } & \multicolumn{4}{|c|}{ Fruit set (\%) } \\
\hline & 2015 & 2016 & 2017 & 2018 \\
\hline Self-rooted BRS Libra (1) & $18.16 \mathrm{~A} \mathrm{C}$ & $31.90 \mathrm{~A} \mathrm{~b}$ & $4.17 \mathrm{C} \mathrm{C}$ & $59.64 \mathrm{Aa}$ \\
\hline BRS Libra/Cadaman (3) & $15.11 \mathrm{~B} \mathrm{~b}$ & $17.79 \mathrm{Cb}$ & $4.03 \mathrm{C} \mathrm{C}$ & $31.58 \mathrm{Ca}$ \\
\hline BRS Libra/Capdeboscq (4) & 15.57 B b & $16.57 \mathrm{Cb}$ & 7.39 B c & $23.89 \mathrm{D} a$ \\
\hline BRS Libra/Clone 15 (5) & $6.96 \mathrm{D} \mathrm{c}$ & $16.70 \mathrm{Cb}$ & $0.90 \mathrm{D} \mathrm{d}$ & $33.41 \mathrm{Ca}$ \\
\hline BRS Libra/Flordaguard (7) & $18.59 \mathrm{~A} \mathrm{a}$ & $13.23 \mathrm{D} \mathrm{b}$ & $1.17 \mathrm{D} \mathrm{c}$ & $24.99 \mathrm{D}$ a \\
\hline BRS Libra/G × N9 (8) & 14.06 B c & 27.17 B b & $3.38 \mathrm{Cd}$ & $50.96 \mathrm{~B}$ a \\
\hline BRS Libra/GF 677 (9) & $14.06 \mathrm{~B} \mathrm{C}$ & $34.57 \mathrm{~A} \mathrm{~b}$ & $3.46 \mathrm{Cd}$ & $65.67 \mathrm{~A} a$ \\
\hline BRS Libra/I-67-52-4 (10) & $18.80 \mathrm{~A} \mathrm{~b}$ & 20.02 B b & 5.04 C c & $48.99 \mathrm{~B}$ a \\
\hline BRS Libra/Ishtara (11) & $19.80 \mathrm{~A} \mathrm{~b}$ & $24.53 \mathrm{~B} \mathrm{~b}$ & $3.88 \mathrm{C} \mathrm{c}$ & $45.18 \mathrm{~B}$ a \\
\hline BRS Libra/Rigitano (16) & $7.48 \mathrm{D} \mathrm{c}$ & $20.09 \mathrm{Cb}$ & $1.16 \mathrm{D} \mathrm{c}$ & $39.03 \mathrm{Ca}$ \\
\hline BRS Libra/Rosaflor (17) & $16.59 \mathrm{~B} \mathrm{~b}$ & $20.53 \mathrm{Cb}$ & $2.76 \mathrm{C} \mathrm{C}$ & $38.28 \mathrm{Ca}$ \\
\hline BRS Libra/Santa Rosa (18) & $4.13 \mathrm{D} \mathrm{b}$ & 13.13 D a & 5.81 в b & $20.44 \mathrm{D}$ a \\
\hline BRS Libra/Late 01 (19) & $11.80 \mathrm{Cb}$ & $17.66 \mathrm{Cb}$ & $3.55 \mathrm{C} \mathrm{c}$ & $31.76 \mathrm{Ca}$ \\
\hline BRS Libra/Tsukuba-1 (20) & $10.50 \mathrm{Cb}$ & $17.61 \mathrm{C} \mathrm{b}$ & $4.35 \mathrm{C} \mathrm{c}$ & $30.86 \mathrm{Ca}$ \\
\hline BRS Libra/Tsukuba-2 (21) & 14.05 B b & $13.73 \mathrm{D} \mathrm{b}$ & $1.59 \mathrm{D} \mathrm{c}$ & $25.85 \mathrm{D} a$ \\
\hline BRS Libra/Tsukuba-3 (22) & $12.28 \mathrm{Cb}$ & $21.74 \mathrm{Ca}$ & $11.47 \mathrm{~A} \mathrm{~b}$ & $32.00 \mathrm{Ca}$ \\
\hline Mean & 14.18 & 20.60 & 3.92 & 37.45 \\
\hline CV (\%) & 15.72 & 17.47 & 38.44 & 18.99 \\
\hline
\end{tabular}

Means followed by the same capital letter do not differ statistically among rootstocks (line) and means followed by the same lower case letter do not differ statistically among years (column) by the Scott-Knott test $(p \leq 0.05)$. 
Table 4. Mean grouping test for fruit yield and alternate bearing index $(I)$ for 22 peach genotypes in four growing seasons, from 2015 to 2018

\begin{tabular}{|c|c|c|c|c|c|}
\hline \multirow[t]{2}{*}{ Genotypes } & \multicolumn{4}{|c|}{ Yield $\left(\mathrm{kg} \mathrm{tree}^{-1}\right)$} & \multirow[t]{2}{*}{1} \\
\hline & 2015 & 2016 & 2017 & 2018 & \\
\hline Self-rooted BRS Libra (1) & $3.06 \mathrm{~A} \mathrm{~b}$ & $24.45 \mathrm{~A} \mathrm{a}$ & $5.66 \mathrm{~A} \mathrm{~b}$ & $31.83 \mathrm{~A} \mathrm{a}$ & $0.28 a$ \\
\hline BRS Libra/Barrier (2) & $2.59 \mathrm{~B} \mathrm{~b}$ & $13.53 \mathrm{Ca}$ & $7.17 \mathrm{~A} \mathrm{~b}$ & $15.02 \mathrm{D}$ a & $0.24 \mathrm{a}$ \\
\hline BRS Libra/Cadaman (3) & $2.07 \mathrm{Cb}$ & $18.09 \mathrm{~B} \mathrm{a}$ & $5.50 \mathrm{~A} \mathrm{~b}$ & $13.52 \mathrm{D} \mathrm{a}$ & $0.23 \mathrm{a}$ \\
\hline BRS Libra/Capdeboscq (4) & $3.26 \mathrm{~A} \mathrm{~b}$ & $15.78 \mathrm{Ca}$ & $3.53 \mathrm{Cb}$ & $13.30 \mathrm{D}$ a & $0.20 \mathrm{a}$ \\
\hline BRS Libra/Clone 15 (5) & $1.36 \mathrm{D} \mathrm{b}$ & $14.92 \mathrm{Ca}$ & $2.33 \mathrm{Cb}$ & $20.41 \mathrm{Ca}$ & $0.30 \mathrm{a}$ \\
\hline BRS Libra/G × N9 (8) & $1.01 \mathrm{E} \mathrm{b}$ & $14.29 \mathrm{Ca}$ & $5.64 \mathrm{~A} \mathrm{~b}$ & $22.39 \mathrm{C} \mathrm{a}$ & $0.34 \mathrm{a}$ \\
\hline BRS Libra/GF 677 (9) & $1.28 \mathrm{D} \mathrm{b}$ & $16.94 \mathrm{Ca}$ & $5.86 \mathrm{~A} \mathrm{~b}$ & $11.68 \mathrm{D}$ a & $0.24 \mathrm{a}$ \\
\hline BRS Libra/I-67-52-4 (10) & $3.07 \mathrm{~A} \mathrm{~b}$ & $20.32 \mathrm{~B} \mathrm{a}$ & $4.47 \mathrm{~B} \mathrm{~b}$ & $20.60 \mathrm{Ca}$ & $0.25 \mathrm{a}$ \\
\hline BRS Libra/Ishtara (11) & $3.34 \mathrm{~A} \mathrm{~b}$ & $8.69 \mathrm{D}$ a & $2.82 \mathrm{Cb}$ & $6.84 \mathrm{E} \mathrm{a}$ & $0.12 b$ \\
\hline BRS Libra/México Fila 1 (12) & $3.13 \mathrm{~A} \mathrm{~b}$ & $19.29 \mathrm{~B} \mathrm{a}$ & $5.73 \mathrm{~A} \mathrm{~b}$ & $20.39 \mathrm{Ca}$ & $0.25 \mathrm{a}$ \\
\hline BRS Libra/Rigitano (16) & $0.78 \mathrm{E} \mathrm{b}$ & $11.94 \mathrm{D}$ a & $2.05 \mathrm{D} \mathrm{b}$ & $8.48 \mathrm{E} \mathrm{a}$ & $0.26 \mathrm{a}$ \\
\hline BRS Libra/Rosaflor (17) & $2.15 \mathrm{Cb}$ & $22.23 \mathrm{~A} \mathrm{a}$ & $6.20 \mathrm{~A} \mathrm{~b}$ & $26.91 \mathrm{~B} \mathrm{a}$ & $0.30 \mathrm{a}$ \\
\hline BRS Libra/Santa Rosa (18) & $0.48 \mathrm{~F} \mathrm{~b}$ & $4.39 \mathrm{E} \mathrm{a}$ & $1.19 \mathrm{D} \mathrm{b}$ & $4.13 \mathrm{~F} \mathrm{a}$ & $0.26 \mathrm{a}$ \\
\hline BRS Libra/Late 01 (19) & $1.59 \mathrm{D} \mathrm{b}$ & $14.85 \mathrm{Ca}$ & $4.20 \mathrm{~B} \mathrm{~b}$ & $15.47 \mathrm{Ca}$ & $0.27 \mathrm{a}$ \\
\hline BRS Libra/Tsukuba-1 (20) & $1.85 \mathrm{Cb}$ & $14.45 \mathrm{Ca}$ & $3.43 \mathrm{Cb}$ & $18.27 \mathrm{Ca}$ & $0.28 \mathrm{a}$ \\
\hline BRS Libra/Tsukuba-2 (21) & $1.49 \mathrm{D} \mathrm{b}$ & $16.76 \mathrm{Ca}$ & $3.53 \mathrm{Cb}$ & $24.91 \mathrm{~B} \mathrm{a}$ & $0.31 \mathrm{a}$ \\
\hline BRS Libra/Tsukuba-3 (22) & $1.71 \mathrm{D} \mathrm{b}$ & $17.37 \mathrm{Ca}$ & $3.81 \mathrm{Cb}$ & $20.10 \mathrm{Ca}$ & $0.29 a$ \\
\hline Mean & 2.02 & 15.54 & 4.21 & 17.26 & 0.26 \\
\hline CV (\%) & 14.89 & 15.98 & 27.81 & 19.43 & 17.52 \\
\hline
\end{tabular}

Means followed by the same capital letter do not differ statistically among rootstocks (line) and means followed by the same lower-case letter do not differ statistically among years (column) by the Scott-Knott test ( $p \leq 0.05)$.

According to Miranda et al. (2005), some buds are usually killed even at milder low temperatures, while others are resistant to much lower temperatures. This depends on the stage of fruit bud development, the cultivar, species and cultural practices. Frost resistance among buds of different cultivars of the same species may differ even more than among different species (Pfammatter and Evequoz 1975).

For fruit set percentage, a cluster of the self-rooted genotypes (1) 'GF 677' (9) and 'Mexico Fila 1' (12) for 2016 (Figure 2B) had the highest values of 2016 (Table 3) and 'Clone 15' (5), 'Flordaguard' (7), 'Prunus Mandshurica' (15), 'Santa Rosa' (18) and 'Tsukuba 2' (21) the lowest (Table 2). The fruit set percentage of 'Barrier' (2), 'De Guia' (6), 'Rosaflor' (17) and 'Tsukuba-3' (22) was close to the overall mean (19\%), in other words, these genotypes are the most stable. According to Raseira et al. (2014), a high fruit set implies in higher costs for hand thinning.

The yield levels of the genotypes 'Barrier' (2), 'Cadaman' (3), 'Capdeboscq' (4), 'Clone 15' (5), 'G × N9' (8), 'GF 677' (9), 'Nemared' (13), 'Okinawa' (14), 'Late-01' (19), 'Tsukuba 1' (20) and 'Tsukuba 3' (22) were similar, but below the best mean yield (17.26 kg tree ${ }^{-1}$ in 2018). This contradicts results of Orazem et al (2011), who reported that rootstock Barrier produced highest total yields $\left(>20 \mathrm{~kg}\right.$ tree $\left.^{-1}\right)$.

Prunus mandshurica (15) and Santa Rosa (18) were the most unstable cultivars (Figure 2A), probably due to graft incompatibility. Santa Rosa, a Japanese plum tree (Prunus salicina), is still being tested as peach rootstock for the Brazilian climate conditions, due to its wide genetic variability. This shows that there is a worldwide trend of using hybrid rootstocks or cultivars of other species as scions.

An example is the combination of $P$. persica with rootstock $P$. mandshurica or Santa Rosa $(P$. salicina), to enhance adaptation to the edaphic conditions and raise the yield of the scion cultivar. Between 2014 and 2017, Gonçalves et al. 
(2019) evaluated these rootstocks under a BRS Libra (Prunus persica) scion cultivar and concluded that this combination induced reduced vegetative growth, poor yield performance and poor peach fruit quality of 'BRS- Libra'.

Similarly, in this study, the adaptability and stability of these genotypes (Prunus mandshurica and Santa Rosa), fruit set percentage (Figure $2 \mathrm{~B}$ ) and yield per plant were poor (Figure 2A). Therefore, according to this study, these genotypes are not recommended for a rootstock $\times$ scion combination with cultivar BRS Libra.
Table 5. Phenotypic correlation over the evaluation years for the analyzed variables: Fruit set above and yield per plant below the main diagonal

\begin{tabular}{lllll}
\hline & 2015 & $\mathbf{2 0 1 6}$ & $\mathbf{2 0 1 7}$ & $\mathbf{2 0 1 8}$ \\
\hline $\mathbf{2 0 1 5}$ & 1 & 0.291 & 0.219 & 0.226 \\
$\mathbf{2 0 1 6}$ & $0.509^{*}$ & 1 & 0.153 & $0.969 *$ \\
$\mathbf{2 0 1 7}$ & $0.527^{*}$ & $0.597^{*}$ & 1 & -0.080 \\
$\mathbf{2 0 1 8}$ & 0.382 & $0.872^{*}$ & $0.512^{*}$ & 1 \\
\hline
\end{tabular}

* Significant at $5 \%$ probability by the t-test.

The fruit set of 'GF 677' (9) was $29.44 \%$, whereas yield was low ( $8.94 \mathrm{~kg}$ tree $^{-1}$ ) (Table 4). This indicates that a good fruit set percentage is important, but insufficient to ensure good yields. The reason is that fruit yield is a result of the interaction between different factors, such as rootstock cultivation, management system, cultivation techniques and GE interaction (Minas et al. 2018). Although 'GF 677' is the most commonly used peach rootstock in Spain (50 \% of all rootstocks in peach orchards) and across the Mediterranean region (Reig et al. 2020), in Brazil it is less common, because of its greater vigor but lower yield (Gonçalves et al. 2019).

The treatment without rootstock, with self-rooted seedlings (1), produced a significantly higher fruit set percentage as well as fruit yield, in all four evaluation years. Moreover, alternate bearing $(1<0.3)$ was not observed, neither for the self-rooted nor all the other rootstocks (Table 4). This cropping patterns is undesirable in orchards, for causing yield surpluses and deficits and affecting many aspects of crop management, e.g.: price, marketing, fruit quality and labor demand (Rosenstock et al. 2010). Peach trees without alternate bearing are desirable. In an evaluation of the yield performance of peach genotypes, Souza et al. (2013) selected those genotypes with lowest levels of alternate bearing.

The use of self-rooted trees is a good option to reduce the production costs of tree nurseries and maintain all genetic characteristics of the scion cultivar. However, in Brazil this technique is not used commercially, due to a lack of field studies that provide proof for the high yield, productivity, fruit quality, low GE interaction, as well as the longevity and integrity of self-rooted in comparison with grafted plants.

Different growing seasons were positively correlated with yield per year (Table 5). For both fruit set and yield, the growing seasons of 2016 and 2018 were highly correlated, indicating a similar behavior. On the other hand, in the growing seasons of 2017 and 2018, correlations became negative for fruit set, indicating a contrasting pattern between the years.

Thus, the growing season of 2018 was strongly correlated with that of 2016. In these two growing seasons, the mean yield and fruit set per plant were the highest (Table 2).

Therefore, low adaptability and stability of fruit set and yield was concluded for the genotypes Prunus mandshurica and Santa Rosa. Under the tested experimental conditions, the adaptability and stability of the self-rooted genotypes of cultivar BRS Libra was higher, which is therefore recommended as a potential alternative option for producers. The GGE biplot methodology was successful in classifying peach genotypes in terms of adaptability and stability of fruit set and yield.

\section{REFERENCES}

Abreu HKA, Ceccon G, Correa AM, Fachinelli R, Yamamoto ELM and Teodoro PE (2019) Adaptability and stability of cowpea genotypes via REML/BLUP and GGE BIPLOT. Bioscience Journal 35: 1071-1082.

Couto MF, Nascimento M, Amaral AT, Silva FF and Viana AP (2015) Visas Eberhart and Russel's bayesian method in the selection of popcorn cultivars. Crop Science 55: 571-577.

Cruz CD (2006) Programa Genes: Biometria. Editora UFV, Viçosa, 382p.

Dias SD, Carlos T and Krzanowski WJ (2003) Model selection and cross validation in additive main effect and multiplicative interaction models. Crop Science 43: 865-873.

Dogra RK and Kumar P (2018) Variability and character association studies of yield and its contributing traits in low chilling peach, Prunus persica (L) Batsch genotypes. International Journal of Farm Sciences 8: 120-126.

Eberhart SA and Russell WA (1996) Stability parameters for comparing varieties. Crop Science 6: 36-40.

Fadón E, Fernandez E, Behn H and Luedeling E (2020) A conceptual framework for winter dormancy in deciduous trees. Agronomy 10: 241-261. 
Forcada CF, Gogorcena Y and Moreno MÁ (2014) Agronomical parameters, sugar profile and antioxidant compounds of "Catherine" peach cultivar influenced by different plum rootstocks. International Journal of Molecular Sciences 15: 2237-2254.

Forcada CF, Reig G, Giméne ZR, Mignard P, Mestre L and Moreno MÁ (2019) Sugars and organic acids profile and antioxidant compounds of nectarine fruits influenced by different rootstocks. Scientia Horticulturae 248: 145-153.

Fumuro M (2019) Comparison of growth, yield, and fruit quality of potplanted mango cv. Aikou using own-rooted trees propagated by air layering and grafted trees propagated by conventional methods. HortScience 54: 1175-1180.

Gonçalves ED, Monteiro VFC, Mayer NA, Moura PHA, Alvarenga ÂA, Antunes LEC, Trevisan R and Pádua JG (2019) Desempenho de pessegueiro 'BRS Libra' autoenraizado e enxertado sobre portaenxertos clonais em Minas Gerais. Brazilian Journal of Agricultural Sciences 14: 1981-1997.

Grossman YL and Dejong TM (1998) Training and pruning system effects on vegetative growth potential, light interception, and cropping efficiency in peach trees. Journal-American Society for Horticultural Science 123: 1058-1064.

Hadasch S, Forkman J and Piepho H (2017) Cross-validation in AMMI and GGE models: A comparison of methods. Crop Science 57: 264-274.

Hoblyn T, Grubb A, Painter A and Wates B (1936) Studies in biennial bearing I. Journal of Pomology and Horticultural Science 14: 39-76.

Iglesias I, Giné-Bordonaba J, Garanto X and Reig G (2019) Rootstock affects quality and phytochemical composition of 'Big Top' nectarine fruits grown under hot climatic conditions. Scientia Horticulturae 256: 108586.

Jimenes IM, Mayer NA, dos Santos, CTD, Scarpare JAF and da Silva SR (2018) Influence of clonal rootstocks on leaf nutrient content, vigor and productivity of young 'Sunraycer' nectarine trees. Scientia Horticulturae 235: 279-285.

Luz LND, Santa-Catarina R, Barros GB, Barros FR, Vettorazzi JCF and Pereira MG (2018) Adaptability and stability of papaya hybrids affected by production seasonality. Crop Breeding and Applied Biotechnology 18: 357-364.

Mayer NA, Ueno B, Nava G and Neves TRD (2018) Leaf nutrient content on seven plum cultivars with grafted by budding or own-rooted trees. Revista Brasileira de Fruticultura 40: 1-12.

Mestre L, Reig G, Betran JA and Moreno MA (2017) Influence of plum rootstocks on agronomic performance, leaf mineral nutrition and fruit quality of 'Catherina' peach cultivar in heavy-calcareous soil conditions. Spanish Journal of Agricultural Research 15: 901-912.

Minas IS, Tanou G and Molassiotis A (2018) Environmental and orchard bases of peach fruit quality. Scientia Horticulturae 235: 307-322.
Miranda C, Santesteban LG and Royo JB (2005) Variability in the relationship between frost temperature and injury level for some cultivated Prunus species. HortScience 40: 357-361.

Orazem P, Stampar F and Hudina M (2011) Quality analysis of 'Redhaven' peach fruit grafted on 11 rootstocks of different genetic origin in a replant soil. Food Chemistry 124: 1691-1698.

Patil S, Shinde M, Prashant R, Kadoo N, Upadhyay A and Gupta VS (2019) Comparative proteomics unravels the differences in salt stress response of own rooted and 110r grafted Thompson seedless grapevines. Journal of Proteome Research 19: 583-599.

Pfammatter W and Evequoz M (1975) Frost resistance of different crops. Revue Suisse De Viticulture, Arboriculture, Horticulture 7: 19-23.

Pio R, Souza FBMD, Kalcsits L, Bisi RB and Farias DDH (2019) Advances in the production of temperate fruits in the tropics. Acta Scientiarum. Agronomy 41: 2-6.

R Core Team (2016) R: A language and environment for statistical computing. R Foundation for Statistical Computing,Vienna, 665p.

Raseira MCB, Nakasu BH, Pereira JFM and Citadin I (2010) 'BRS Libra': cultivar de pessegueiro lançada pela EMBRAPA, em 2009. Revista Brasileira de Fruticultura 32: 1272-1274.

Raseira MDCB, Pereira JFM and Carvalho FLC (2014) Pessegueiro. Embrapa, Brasília, 776p.

Reig G, Garanto X, Mas N and Iglesias I (2020) Long-term agronomical performance and iron chlorosis susceptibility of several Prunus rootstocks grown under loamy and calcareous soil conditions. Scientia Horticulturae 262: 109035.

Rosenstock TS, Rosa UA, Plant RE and Brown PH (2010) A reevaluation of alternate bearing in pistachio. Scientia Horticulturae 124: 149-152.

Scariotto S, Citadin I, Raseira MDCB, Sachet MR and Penso GA (2013) Adaptability and stability of 34 peach genotypes for leafing under Brazilian subtropical conditions. Scientia Horticulturae 155: 111-117.

Souza FBM, Alvarenga AA, Pio R, Gonçalvez ED and Patto LS (2013) Fruit production and quality of selections and cultivars of peach trees in Serra da Mantiqueira, Brazil. Bragantia 72: 133-139.

Vaezi B, Pour-Aboughadareh A, Mehraban A, Hossein-Pour T, Mohammadi $\mathrm{R}$, Armion $\mathrm{M}$ and Dorri $\mathrm{M}$ (2018) The use of parametric and nonparametric measures for selecting stable and adapted barley lines. Archives of Agronomy and Soil Science 64: 597-611.

Yamamoto LY Koyama R, Borges WFS, Antunes LEC, Assis AM and Roberto SR (2013) Substratos no enraizamento de estacas herbáceas de amora-preta Xavante. Ciência Rural 43: 1-6.

Yan W and Kang MS (2003) GGE Biplot analysis: a graphical tool for breeders, geneticists, and agronomists. CRC Press LLC, Boca Raton, 271p.

(cc) EY This is an Open Access article distributed under the terms of the Creative Commons Attribution License, which permits unrestricted use, distribution, and reproduction in any medium, provided the original work is properly cited. 